\title{
Thermal expansion studies of substituted CTP derivatives
}

\author{
A K GANGULI* and K P JAYADEVAN \\ CSIR Centre of Excellence in Chemistry, Indian Institute of Science, Bangalore 560012, India \\ MS received 7 April 1995; revised 23 September 1995 \\ Abstract. Several new $\mathrm{Na}, \mathrm{Y}$ and $\mathrm{Zr}$ substituted derivatives of $\mathrm{Ca}_{0 \cdot 5} \mathrm{Ti}_{2}\left(\mathrm{PO}_{4}\right)_{3}(\mathrm{CTP})$ have \\ been synthesized. These derivatives retain the hexagonal structure of the parent (CTP) \\ compound with minor changes in lattice parameters. Linear thermal expansion coefficients $(\alpha)$ \\ have been obtained using a high sensitivity dilatometer.
}

Keywords. CTP; phosphates; thermal expansion.

\section{Introduction}

$\mathrm{Ca}_{0.5} \mathrm{Ti}_{2}\left(\mathrm{PO}_{4}\right)_{3}$ and $\mathrm{NaZr}_{2}\left(\mathrm{PO}_{4}\right)_{3}$ commonly called CTP and NZP have been the subject of numerous investigations (Goodenough et al 1976; Hong 1976; Roy et al 1984; Alamo and Roy 1986; Ota et al 1989; Limaye et al 1991; Kutty et al 1994) due to their possible applications as ionic conductors and low-thermal expansion materials. Among other possible applications is the ability of the members of the [CTP] family to immobilize radionuclides as reported by Roy et al (1985). The CTP structure consists of $\mathrm{TiO}_{6}$ octahedra and $\mathrm{PO}_{4}$ tetrahedra sharing all their corners such that each $\mathrm{TiO}_{6}$ octahedra is connected to six $\mathrm{PO}_{4}$ tetrahedra and each $\mathrm{PO}_{4}$ tetrahedron connected to four $\mathrm{TiO}_{6}$ octahedra. These units are repeated alternating with $\mathrm{MO}_{6}$ octahedra $(\mathrm{M}=\mathrm{Na}, \mathrm{Ca}$ etc.) along the $c$-axis to form chains which in turn are connected through the phosphate groups to neighbouring chains (figure 1). Such a structural network results in various kinds of holes which are occupied by $\mathrm{Na}$ or $\mathrm{Ca}$ ions in NZP and CTP respectively. The crystal chemistry and details of the range of ionic substitutions possible in the CTP structure have been given by Alamo and Roy (1986). These studies have shown that a rich substitution chemistry is possible in these compounds which bring about a wide-ranging thermal expansion behaviour. The thermal expansion in these materials is anisotropic. The anisotropic behaviour is attributed to the $\mathrm{M}-\mathrm{O}$ bonds $(\mathrm{M}=\mathrm{Na}, \mathrm{Ca})$ which expand more than the other bonds in the network.

Although various ionic substitutions have been carried out in the CTP structure the influence of trivalent rare-earth or $\mathrm{Y}$ ions on the structure and thermal expansion properties is unknown except for one report on $\mathrm{La}_{0.33} \mathrm{Ti}_{2}\left(\mathrm{PO}_{4}\right)_{3}$ (Senbhagaraman and Umarji 1990) although recently several Zr-containing compounds of the type $\mathrm{Ln}_{0.33} \mathrm{Zr}_{2}\left(\mathrm{PO}_{4}\right)_{3}$ have been reported (Alami Talbi et al 1994). We have therefore attempted to synthesize and characterize $Y$ doped CTP materials. Furthermore we have studied $\mathrm{Na}$ doping in $\mathrm{Ca}$ sites and $\mathrm{Zr}$ doping in Ti sites to see the effect on the thermal expansion properties, knowing that $\mathrm{Ca}_{0.5} \mathrm{Ti}_{2}\left(\mathrm{PO}_{4}\right)_{3}$ has a positive linear thermal expansion coefficient $(\alpha)$ while the other end member $\left(\mathrm{NaTi}_{2}\left(\mathrm{PO}_{4}\right)_{3}, \mathrm{Ca}_{0.5} \mathrm{Zr}_{2}\left(\mathrm{PO}_{4}\right)_{3}\right)$ have a negative $\alpha$.

\footnotetext{
*For correspondence
} 


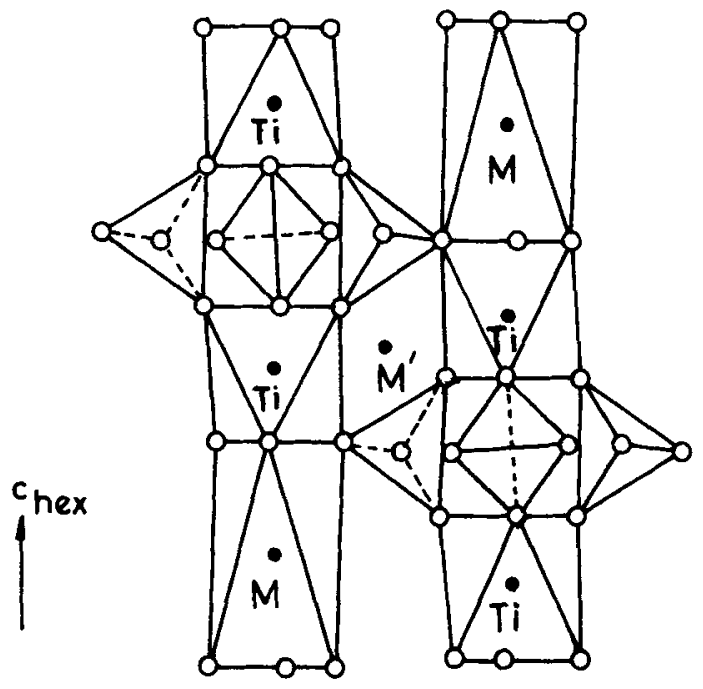

Figure 1. Structural model of CTP, showing the $\mathrm{MO}_{6}$ and $\mathrm{PO}_{4}$ interconnected polyhedra.

In this article we report the synthesis, characterization and thermal expansion studies of the above compounds. We have also studied the effect of codoping $\mathrm{Nb}$ in $\mathrm{Ti}$ sites and $\mathrm{Si}$ in $\mathrm{P}$ sites in $\mathrm{Ca}_{0} \cdot \mathrm{Ti}_{2}\left(\mathrm{PO}_{4}\right)_{3}$.

\section{Experimental}

Pure and doped $\mathrm{Ca}_{0.5} \mathrm{Ti}_{2}\left(\mathrm{PO}_{4}\right)_{3}$ type CTP phases were prepared by solid state reactions. Stoichiometric quantities of $\mathrm{CaCO}_{3}, \mathrm{Na}_{2} \mathrm{CO}_{3}, \mathrm{Y}_{2} \mathrm{O}_{3}, \mathrm{TiO}_{2}, \mathrm{ZrO}_{2}, \mathrm{SiO}_{2}$ (fumed amorphous), $\mathrm{Nb}_{2} \mathrm{O}_{5}$ and $\left(\mathrm{NH}_{4}\right)_{2} \mathrm{HPO}_{4}$ were mixed thoroughly in acetone and dried. The powders were heated at $623 \mathrm{~K}(4 \mathrm{~h})$ and $1173 \mathrm{~K}(18 \mathrm{~h})$. These were mixed with $5 \%$ solution of PVA (few drops) and then pelletized and heated at $1323 \mathrm{~K}$ for $16 \mathrm{~h}$. The $\mathrm{Nb}$ and $\mathrm{Si}$ containing samples were heated only up to a maximum temperature of $1273 \mathrm{~K}$. Powder XRD patterns were obtained at room temperature using a JEOLJDX-8P diffractometer with $\mathrm{CuK} \alpha$ radiation. The lattice parameters were calculated by a least squares fitting procedure of the observed $d$-values.

Thermal expansion measurements were carried out on sintered pellets using a high sensitivity dilatometer based on linearly variable differential transformer (LVDT) principle (Senbhagaraman 1995). The measurements were carried out in the range 300 to $900 \mathrm{~K}$ on samples of length 4 to $6 \mathrm{~mm}$. The temperature was increased at the rate of $2 \cdot 2 \mathrm{~K} / \mathrm{min}$ and measured with an accuracy of $\pm 1 \mathrm{~K}$ using a type $\mathrm{K}$ thermocouple. The coefficient of linear thermal expansion $(\alpha)$ was obtained from the slopes of the $\Delta l / l$ vs temperature plots and had an accuracy of $\pm 0.5 \times 10^{-6} \mathrm{~K}$.

\section{Results and discussion}

The general formula of the CTP structure may be written as $\mathrm{MM}_{3}^{\prime} \mathrm{Ti}_{2} \mathrm{P}_{3} \mathrm{O}_{12}$ where $M$ can be $\mathrm{Na}, \mathrm{Ca}, \mathrm{Sr}$, while $\mathrm{M}^{\prime}$ is mainly $\mathrm{Na}$ or $\mathrm{K}$. The $\mathbf{M}$ and $\mathrm{M}^{\prime}$ ions occupy the holes formed by the network of $\mathrm{PO}_{4}$ and $\mathrm{TiO}_{6}$ units (figure 1). In $\mathrm{NaTi}_{2}\left(\mathrm{PO}_{4}\right)_{3}$ the $\mathrm{M}$ sites are 
Table 1. Lattice parameters and the linear thermal expansion coefficient $(\alpha$ ) for the various CTP type materials studied.

\begin{tabular}{|c|c|c|c|}
\hline \multirow[b]{2}{*}{ Composition } & \multicolumn{2}{|c|}{ Lattice parameters } & \multirow[b]{2}{*}{$x^{\prime}\left(10^{-6} \mathrm{~K}^{-1}\right)$} \\
\hline & $a(\AA)$ & $c(\AA)$ & \\
\hline $\mathrm{Ca}_{0.5} \mathrm{Ti}_{2}\left(\mathrm{PO}_{4}\right)_{3}$ & $8 \cdot 347(3)$ & $21.95(1)$ & $6.5^{-}$ \\
\hline $\mathrm{Ca}_{0.4}^{0.5} \mathrm{Na}_{0.2}^{2} \mathrm{Ti}_{2}^{4}\left(\mathrm{PO}_{4}\right)_{3}$ & $8.371(4)$ & $21.91(2)$ & $6 \cdot 3$ \\
\hline $\mathrm{Ca}_{0.3}^{0.4} \mathrm{Na}_{0.4}^{0.2} \mathrm{Ti}_{2}\left(\mathrm{PO}_{4}^{4 / 3}\right)_{3}$ & $8.410(2)$ & $21 \cdot 915(7)$ & $7 \cdot 0$ \\
\hline $\mathrm{Ca}_{0.35}^{0.3} \mathrm{Y}_{0.1}^{0.4} \mathrm{Ti}_{2}^{2}\left(\mathrm{PO}_{4}\right)_{3}^{3}$ & $8 \cdot 349(3)$ & $21 \cdot 90(1)$ & $6 \cdot 8$ \\
\hline $\mathrm{Ca}_{0.4} \mathrm{Y}_{0.1} \mathrm{Ti}_{2}\left(\mathrm{PO}_{4}\right)_{3}^{3}$ & $8 \cdot 339(3)$ & $21 \cdot 89(1)$ & $7 \cdot 1$ \\
\hline $\mathrm{Ca}_{0.3}^{0.4} \mathrm{Na}_{0.1} \mathrm{Y}_{0.1}^{2} \mathrm{Ti}_{2}^{4}\left(\mathrm{PO}_{4}\right)_{3}$ & $8 \cdot 360(3)$ & $21 \cdot 91(1)$ & $7 \cdot 0$ \\
\hline $\mathrm{Ca}_{0.5} \mathrm{Ti}_{1.9} \mathrm{Zr}_{0.2}\left(\mathrm{PO}_{4}\right)_{3}^{4.3}$ & $8.362(4)$ & $21 \cdot 93(2)$ & $9 \cdot 4$ \\
\hline $\mathrm{Ca}_{0.5}^{0.5} \mathrm{Ti}_{1.75} \mathrm{Zr}_{0.25}^{0.2}\left(\mathrm{PO}_{4}\right)_{3}^{*}$ & $8 \cdot 346(3)$ & $21 \cdot 94(1)$ & $8 \cdot 7$ \\
\hline $\mathrm{Ca}_{0.5} \mathrm{Ti}_{1.9} \mathrm{Nb}_{0.1} \mathrm{P}_{2.9} \mathrm{Si}_{0.1}^{4} \mathrm{O}_{12}$ & $8 \cdot 387(3)$ & $21 \cdot 96(1)$ & $6 \cdot 8$ \\
\hline $\mathrm{Ca}_{0.5} \mathrm{Ti}_{1.8} \mathrm{Nb}_{0.2} \mathrm{P}_{2.8} \mathrm{Si}_{0.2} \mathrm{O}_{12}$ & $8 \cdot 396(2)$ & $21 \cdot 962(8)$ & $7 \cdot 7$ \\
\hline
\end{tabular}

${ }^{+}$Reported value $5.1 \times 10^{-6}$; Roy et al 1984

$* \mathrm{ZrO}_{2}(5 \%)$ impurity present.
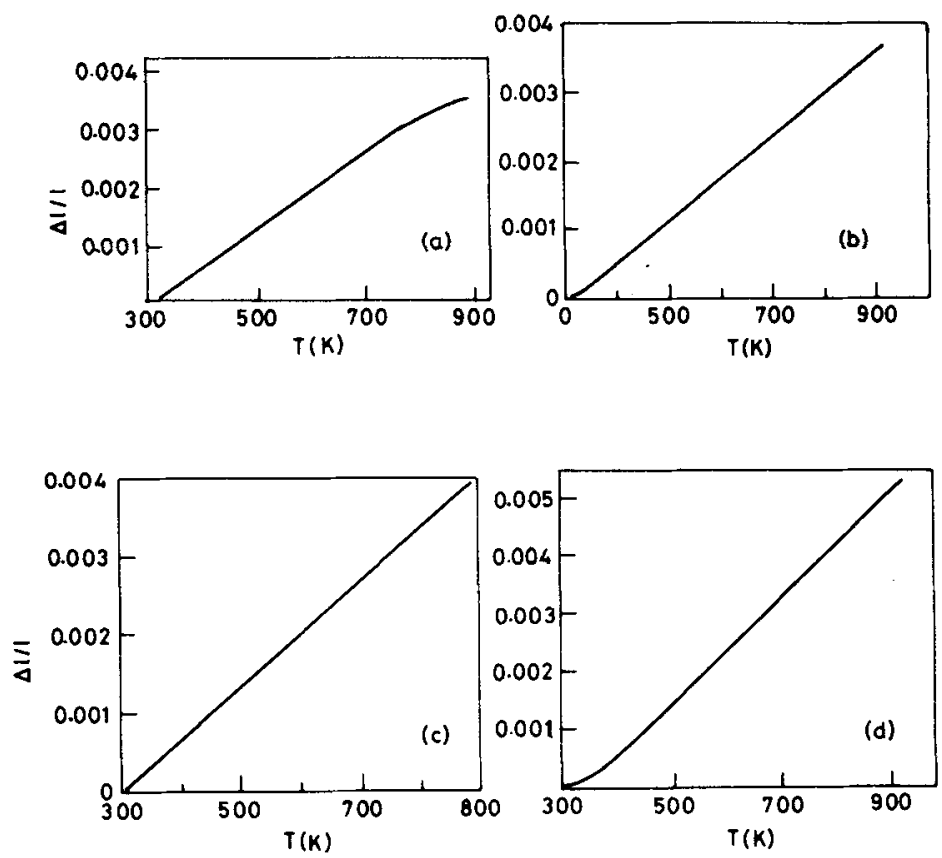

Figure 2. Variation of $(\Delta / / /)$ with temperature for (a) $\mathrm{Ca}_{0.5} \mathrm{Ti}_{2}\left(\mathrm{PO}_{4}\right)_{3}$, (b) $\mathrm{Ca}_{0.4} \mathrm{Na}_{0.2} \mathrm{Ti}_{2}$ $\left(\mathrm{PO}_{4}\right)_{3}$, (c) $\mathrm{Ca}_{0.35} \mathrm{Y}_{0.1} \mathrm{Ti}_{2}\left(\mathrm{PO}_{4}\right)_{3}$ and (d) $\mathrm{Ca}_{0.5} \mathrm{Ti}_{1.9} \mathrm{Zr}_{0.1}\left(\mathrm{PO}_{4}\right)_{3}$.

fully occupied while in $\mathrm{Ca}_{0.5} \mathrm{Ti}_{2}\left(\mathrm{PO}_{4}\right)_{3}$ only half of these sites are filled. In both these cases the $\mathrm{M}^{\prime}$ sites are empty. In compositions like $\mathrm{Na}_{1+x} \mathrm{Zr}_{2} \mathrm{P}_{3-x} \mathrm{Si}_{x} \mathrm{O}_{12}$ (NASICON) the excess $\mathrm{Na}(\mathrm{x})$ goes into the $\mathrm{M}^{\prime}$ sites. The compositions chosen by us (table 1 ) aim to replace the $\mathrm{Ca}$ ions by $\mathrm{Y}$ or $\mathrm{Na}$ or both. Table 1 lists the various compositions, the refined lattice parameters (hexagonal lattice) and the average coefficient of linear thermal expansion $(x)$. It is to be noted that all the compositions chosen are charge 
balanced except for one, $\mathrm{Ca}_{0 \cdot 4} \mathrm{Y}_{0 \cdot 1} \mathrm{Ti}_{2}\left(\mathrm{PO}_{4}\right)_{3}$. From the powder XRD patterns all the phases obtained were pure except in the $\mathrm{Ca}_{0.5} \mathrm{Ti}_{1.75} \mathrm{Zr}_{0.75}\left(\mathrm{PO}_{4}\right)_{3}$ sample which had $\sim 5 \% \mathrm{ZrO}_{2}$ impurities. Earlier reports (Roy et al 1984) also find impurity phases like $\mathrm{ZrO}_{2}$ or $\mathrm{ZrP}_{2} \mathrm{O}_{7}$ in $\mathrm{Zr}$ rich samples.

In figure 2 we show some representative plots of $(\Delta l / l)$ as a function of temperature. We find that the plots are nearly linear. In $\mathrm{Ca}_{0.5} \mathrm{Ti}_{2}\left(\mathrm{PO}_{4}\right)_{3}$ (figure 1a) we find that the plot deviates from linearity at high temperatures, beyond $750 \mathrm{~K}$.

The lattice parameters of $\mathrm{Ca}_{0.5} \mathrm{Ti}_{2}\left(\mathrm{PO}_{4}\right)_{3}$ is close to that reported in the literature. The ' $\alpha$ ' value of $\mathrm{Ca}_{0.5} \mathrm{Ti}_{2}\left(\mathrm{PO}_{4}\right)_{3}, 6.5 \times 10^{-6} / \mathrm{K}$ is slightly higher than that reported earlier (Roy et al 1984). Since these are average $\alpha$ values, measured on polycrystalline samples such deviation may be explained due to microstructural differences among these samples. The Na-doped samples show an increase in the a-parameter and a decrease in the c-parameter compared to the pure CTP phase. The ' $\alpha$ ' values fall from $6.5 \times 10^{-6} / \mathrm{K}$ in the $\mathrm{Ca}_{0.5} \mathrm{Ti}_{2}\left(\mathrm{PO}_{4}\right)_{3}$ to $6.3 \times 10^{-6} / \mathrm{K}$ in $\mathrm{Ca}_{0.4} \mathrm{Na}_{0.2} \mathrm{Ti}_{2}\left(\mathrm{PO}_{4}\right)_{3}$ which is what one would expect since the end member, $\mathrm{NaTi}_{2}\left(\mathrm{PO}_{4}\right)_{3}$, has an $\alpha$ of $-5 \cdot 5 \times 10^{-6} / \mathrm{K}$. But on increasing the $\mathrm{Na}$ content further, e.g. $\mathrm{Ca}_{0 \cdot 3} \mathrm{Na}_{0 \cdot 4} \mathrm{Ti}_{2}\left(\mathrm{PO}_{4}\right)_{3}$ we note that the $\alpha$ value of $7 \cdot 0 \times 10^{-6} / \mathrm{K}$ is slightly larger than for pure CTP. It should however be noted that in $\mathrm{NaTi}_{2}\left(\mathrm{PO}_{4}\right)_{3} \alpha$ is highly sample dependent as the thermal expansion anisotropy is very high $\left(\alpha_{\mathrm{c}}-\alpha_{\mathrm{a}}=24 \times 10^{-6} / \mathrm{K}\right)$ (Rodrigo et al 1989; Senbhagaraman and Umarji 1990). So unless the microstructural effects are minimized it is difficult to predict how each ceramic sample of the solid solution would behave.

On substituting $\mathrm{Y}$ or $\mathrm{Na}+\mathrm{Y}$ at the $\mathrm{Ca}$ sites the a-parameter does not change significantly while the c-parameter decreases (table 1). The ' $\alpha$ ' values are slightly higher than that of pure CTP. Substituting $\mathrm{Zr}$ in the Ti sites leads to minor changes
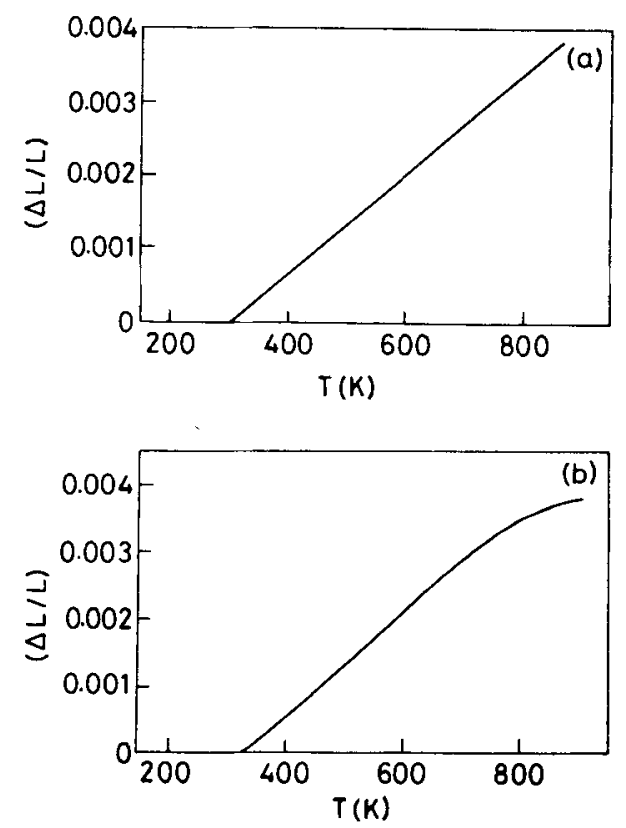

Figure 3. Variation of $(\Delta l / l)$ with temperature for (a) $\mathrm{Ca}_{0.5} \mathrm{Ti}_{1 \cdot 9} \mathrm{Nb}_{0.1} \mathrm{P}_{2 \cdot 9} \mathrm{Si}_{0.1} \mathrm{O}_{12}$ and (b) $\mathrm{Ca}_{0 \cdot 5} \mathrm{Ti}_{1 \cdot 8} \mathrm{Nb}_{0 \cdot 2} \mathrm{P}_{2 \cdot 8} \mathrm{Si}_{0 \cdot 2} \mathrm{O}_{12}$. 
in the lattice parameters, but the $x$-values are significantly higher $\left(\sim 9 \times 10^{-6} / \mathrm{K}\right)$ than pure CTP.

We have simultaneously substituted small amounts of $\mathrm{Nb}$ in Ti sites and $\mathrm{Si}$ in $\mathrm{P}$ sites (to maintain charge balance). We obtain nearly pure phases of the type $\mathrm{Ca}_{0.5} \mathrm{Ti}_{2-x} \mathrm{Nb}_{x} \mathrm{P}_{3-x} \mathrm{Si}_{x} \mathrm{O}_{12}(x \leqslant 0 \cdot 2)$. Our studies have shown that fumed amorphous silica needs to be used for these reactions to obtain monophasic samples. We also note very minor amounts of $\mathrm{TiO}_{2}(\sim 2 \%)$ as impurity if heated to higher temperatures $\left(>1000^{\circ} \mathrm{C}\right)$ and longer periods. The expansion $(\Delta l / l)$ was linear with temperature till $870^{\circ} \mathrm{C}$ in the $x=0.1$ sample but deviated from linearity for the $x=0.2$ sample after $750^{\circ} \mathrm{C}$ (figure 3). $\alpha$ increases with $x$ as seen in table 1 and is larger than that of CTP.

\section{Conclusions}

The above study shows that various substitutions like $\mathrm{Na}, \mathrm{Y}, \mathrm{Na}+\mathrm{Y}$ can be carried out in the CTP host lattice. The linear thermal expansion coefficients $(\alpha)$ are however close to that of CTP. The study also shows that substitution is also possible at Ti sites by $\mathrm{Zr}$ where the $\alpha$ values are larger than the parent value. Simultaneous substitution of $\mathrm{Nb}$ at Ti site and Si at P site also does not lower the $\alpha$ values.

\section{Acknowledgements}

The authors thank Prof. CN R Rao for his advice and encouragement. They also thank Dr A M Umarji for providing facilities for thermal expansion measurements and helpfut discussions.

\section{References}

Alami Talbi M, Brochu R, Parent C, Rabardel L and Le Flem G 1994 J. Solid State Chem. 110350 Alamo J and Roy R 1986 J. Mater. Sci. 21444 Goodenough J B, Hong H Y and Kafalas J A 1976 Mater. Res. Bull. 11203 Hong H Y 1976 Mater. Res. Bull. 11173

Kutty K V G, Asuvathraman R, Mathews C K and Varadaraju U V 1994 Mater. Res. Bull. 291009 Limaye S Y, Agrawal D K, Roy R and Mehrotra Y 1991 J. Mater. Sci. 2693

Ota T, Jin P and Yamai I 1989 J. Mater. Sci. 244339

Rodrigo J L, Carrasco P and Alamo J 1989 Mater. Res. Bull. 24611

Roy R, Agrawal D K, Alamo J and Roy R A 1984 Mater. Res. Bull. 19471

Roy R, Vance E R and Alamo J 1985 Mater. Res. Bull. 17585

Senbhagaraman S $1995 \mathrm{Ph}$. D. Thesis, Indian Institute of Science, Bangalore

Senbhagaraman S and Umarji A M 1990 J. Solid State Chem. 85169 